\title{
Freshwater snails and schistosomiasis mansoni in the state of Rio de Janeiro, Brazil: VI - Noroeste Fluminense Mesoregion
}

\author{
Silvana C Thiengo/ ${ }^{+}$, Aline C Mattos, Sonia B Santos*, Monica A Fernandez \\ Departamento de Malacologia, Instituto Oswaldo Cruz-Fiocruz, Av. Brasil 4365, 21040-900 Rio de Janeiro, RJ, Brasil \\ *Laboratório de Malacologia, Departamento de Zoologia, Instituto de Biologia Roberto Alcantara Gomes, UERJ, \\ Rio de Janeiro, RJ, Brasil
}

\begin{abstract}
In this paper, the last of a series dealing with the survey of freshwater gastropods of the state of Rio de Janeiro, the results of collections carried out in the Noroeste Fluminense Mesoregion from 2002 to 2005 are presented and revealed the occurrence of 20 species: Antillorbis nordestensis; Biomphalaria glabrata; B. straminea; B. tenagophila; Drepanotrema anatinum; D. cimex; D. depressissimum; D. lucidum; Ferrissia $s p$.; Gundlachia ticaga; Gundlachia $s p$.; Heleobia $s p$.; Idiopyrgus $s p$.; Lymnaea columella; Melanoides tuberculatus; Physa acuta; P. marmorata; Plesiophysa guadeloupensis; Pomacea lineata; and Pomacea sp. Concerning the snail hosts of schistosomiasis the three natural vectors were identified and, although no specimens were found harbouring larval forms of Schistosoma mansoni, different kinds of cercariae had been observed.
\end{abstract}

Key words: freshwater snails - schistosomiasis mansoni - cercariae - Rio de Janeiro - Brazil

This study is the last of a series started in 1997 to map the distribution of the freshwater snails of the state of Rio de Janeiro. From November 2002 to July 2005 an intensive and detailed survey was undertaken into waterbodies in the following municipalities of the Noroeste Fluminense Mesoregion: Bom Jesus de Itabapoana, Italva, Itaperuna, Laje do Muriaé, Natividade, Porciúncula, and Varre-Sai (Microregion Itaperuna); Aperibé, Cambuci, Itaocara, Miracema, Santo Antônio de Pádua, and São José de Ubá (Microregion Santo Antônio de Pádua).

The freshwater species listed include specimens collected by the authors as well as those in the Collection of the Department of Malacology of Instituto Oswaldo Cruz (CMIOC). An account of the number of schistosomiasis cases reported to this region during the last five years, a map showing the distribution of the alien species Melanoides tuberculatus (Müller, 1774) and the species of medical and veterinary importance, as well as the various kinds of cercariae found in the specimens collected are also presented.

\section{MATERIALS AND METHODS}

As in the previous papers we have adopted the "Instituto Brasileiro de Geografia e Estatística" (IBGE 1995) procedures in dividing the state of Rio de Janeiro into six Mesoregions (Baixadas, Metropolitana, Centro Fluminense, Sul Fluminense, Norte Fluminense, and Noroeste Fluminense) and the Center of Information and Data of Rio de Janeiro (CIDE 2001), which includes the São José do Ubá municipality. The Noroeste Fluminense Mesoregion is $5.373,9 \mathrm{~km}^{2}$, constituting $12.26 \%$ of the state.

${ }^{+}$Correponding author: sthiengo@ioc.fiocruz.br

Received 25 May 2006

Accepted 26 June 2006
The molluscs were collected from different suitable snail habitats from all 50 districts of the 13 municipalities surveyed. Since at least three different habitats were investigated in each of the districts, an average of 202 samples was obtained. Live snails were kept at the laboratory for a month in aquaria containing dechlorinated tap water and, at the bottom, a thin layer of a 2:1 mixture of screened soil and ground oyster shells as a source of mineral nutrients. Snails were fed on fresh lettuce leaves. In the meantime all specimens were exposed to artificial light at five-day intervals to determine possible infection with trematode larvae. Cercariae were fixed in $70 \%$ ethanol, stained with chloridric carmine, mounted in Canada balsam and subsequently identified according to Schell (1970).

The 10 larger specimens of each sample were preserved in Railliet-Henry's fluid after relaxation in a $0.05 \%$ hypnol solution and two of them were dissected under stereomicroscope for identification. Samples of taxonomic importance were deposited at the Malacological Collection of Instituto Oswaldo Cruz.

The cases of schistosomiasis mansoni reported from June 2000 to June 2005 were obtained from the "Gerência Técnica de Esquistossomose - Ministério da Saude".

\section{RESULTS}

Table I shows the localities where the 20 molluscan species were found: Antillorbis nordestensis (Lucena, 1954); Biomphalaria glabrata (Say, 1818); Biomphalaria straminea (Dunker, 1848); Biomphalaria tenagophila (Orbigny, 1835); Drepanotrema anatinum (Orbigny, 1835); Drepanotrema cimex (Moricand, 1839); Drepanotrema depressissimum (Moricand, 1839); Drepanotrema lucidum (Pfeiffer, 1839); Ferrissia sp.; Gundlachia ticaga (Marcus \& Marcus, 1962); Gundlachia sp.; Heleobia sp.; Idiopyrgus sp.; Lymnaea columella Say, 1817; M. tuberculatus; Physa acuta Draparnaud, 1805; Physa marmorata Guilding, 1828; Plesiophysa guadeloupensis ("Fischer" Mazé, 1883); Pomacea lineata (Spix, 1827); and Pomacea sp. 


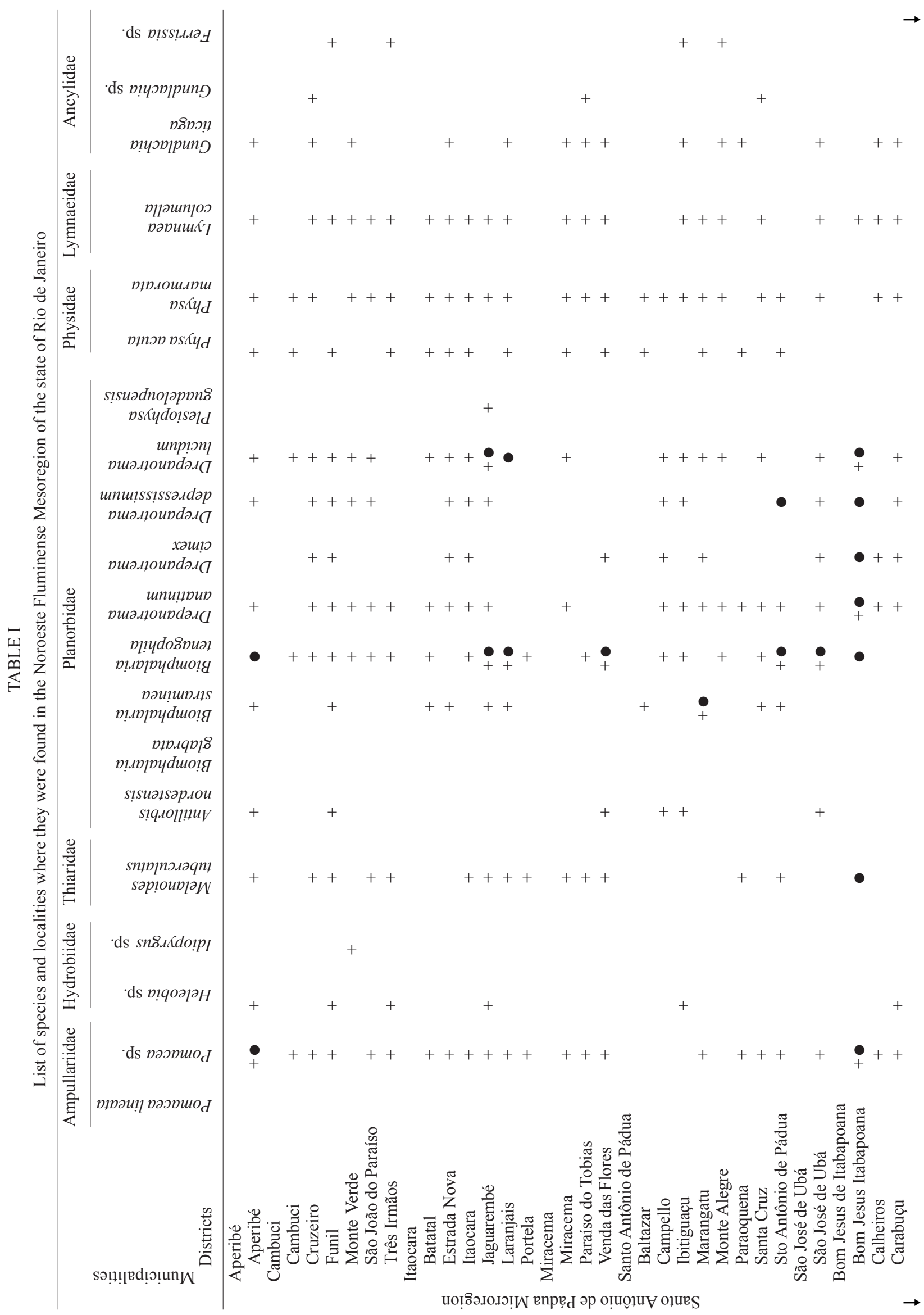




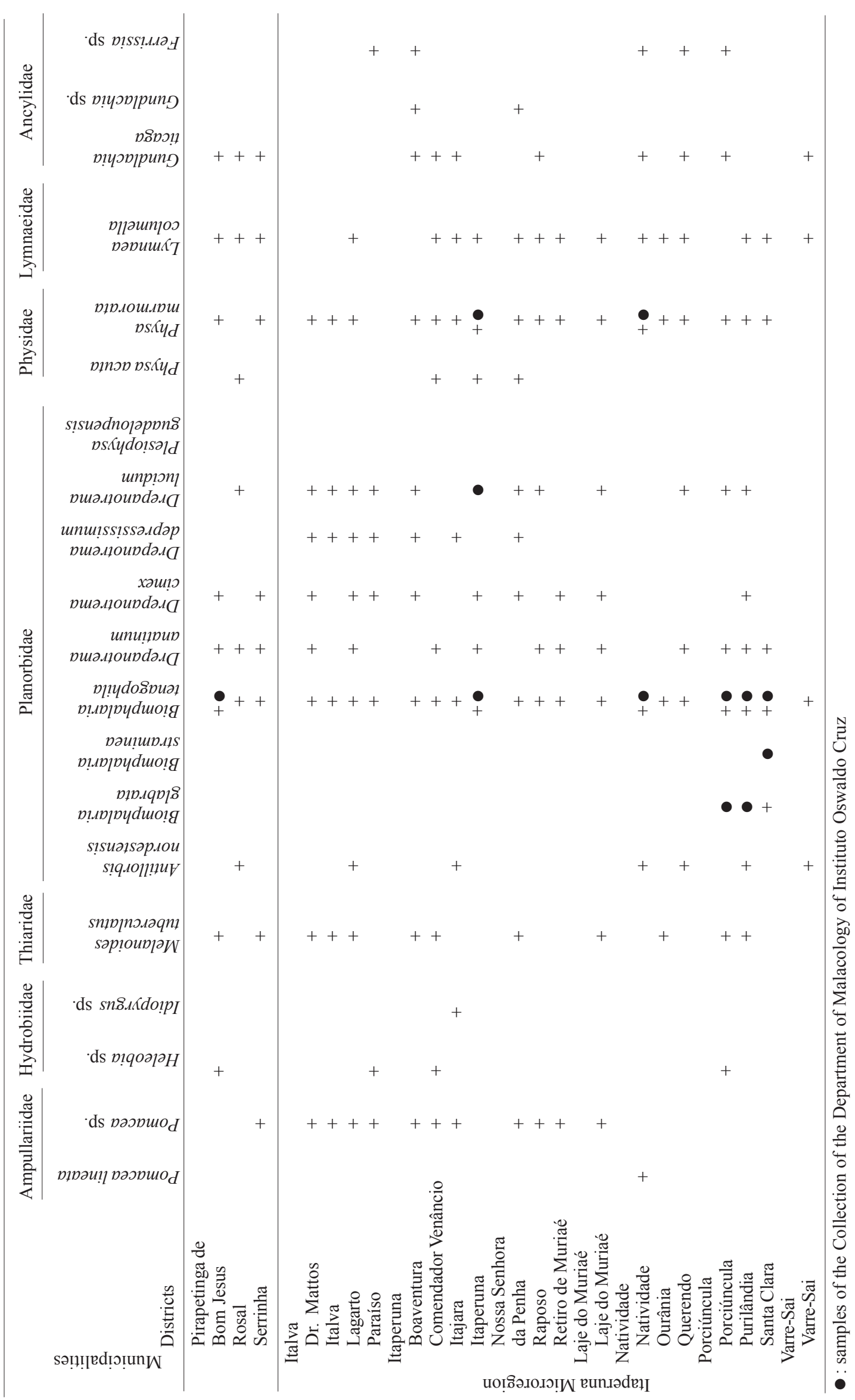


The distribution of the three vectors of Schistosoma mansoni Sambon, 1907 and L. columella, the intermediate host of Fasciola hepatica (Linné) in Brazil, as well as that of the introduced species $M$. tuberculatus are shown in the Figure.

The highest species richness occurred in Cambuci (17 species), Itaperuna (16 species), and Santo Antônio de Pádua (16 species). On the other hand, in Varre-Sai only four species were found. Among the planorbid species $B$. tenagophila was the most frequent, occurring in all municipalities, observed in 43 out of the 50 districts surveyed. Similarly, specimens of $P$. marmorata were found in all municipalities (43 districts) except Varre-Sai. The congeneric species $P$. acuta was observed in 18 districts, but only in Laranjais district (municipality of Itaocara) it was found in the same river with specimens of $P$. marmorata.

In relation to the Prosobranchia species, the most frequent was Pomacea sp. (35 districts), followed by $M$. tuberculatus (27 districts), and Heleobia sp. (10 districts). Specimens of $P$. lineata and Idiopyrgus sp. were found only in one and two districts, respectively.

Although many different kinds of cercariae had been observed (Table II), no specimens were found infected with S. mansoni or F. hepatica. The greatest number of mollusc-parasite interactions was observed in $B$. tenagophila, including 12 possible families of Trematoda: Echinostomatidae (Cambuci, Italva, Itaocara and Santo
Antônio de Pádua municipalities), Haplometridae or Macroderoidae (Laje do Muriaé and Santo Antônio de Pádua), Microphallidae (Cambuci and Porciúncula), Strigeidae or Diplostomatidae (Italva and Santo Antônio de Pádua) and others Xiphidiocercariae (Bom Jesus de Itabapoana and Itaocara). The major diversity of cercariae was found in Cambuci and Santo Antônio de Pádua, shedded from B. tenagophila, D. depressissimum. D. lucidum, L. columella, and Pomacea sp.

Even though no specific parasitological surveys have been performed in the Noroeste Fluminense Mesoregion, cases of schistosomiasis were detected in Porciúncula. From 2000 to 2005, 37 positive schistosomiasis cases were notified, being 14 in 2003 ( 1 in February, 3 in March, 4 in April, 3 in June, and 3 in July) and 23 in 2004 (1 in January, 1 in February, 6 in March, 3 in April, 3 in May, 3 in June, 1 in August, 4 in November, and 1 in December).

\section{DISCUSSION}

In agreement with the Metropolitan, Centro and Sul Fluminense Mesoregions (Thiengo et al. 2001, 2002a, 2004a), the occurrence of the three natural vectors of S. mansoni was observed in the Noroeste Fluminense Mesoregion. From 1984 to 1986 we received samples of freshwater gastropods from many localities of the eight municipalities of the Noroeste Fluminense Mesoregion (Cambuci, Bom Jesus de Itabapoana, Itaocara, Itaperuna,

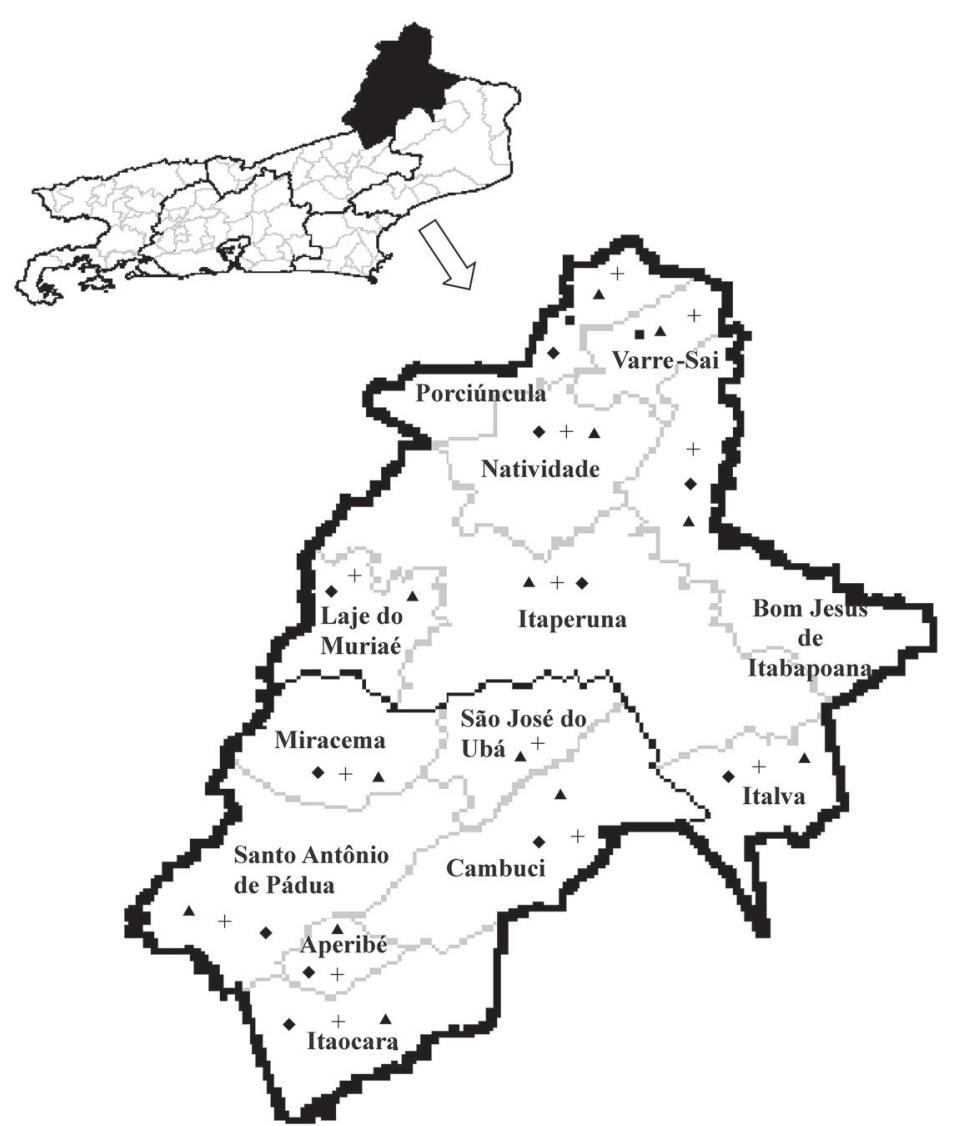

Map showing the distribution of the species of medical and veterinary importance as well as the invasive gastropod competitor of planorbid intermediate hosts of Schistosoma mansoni. (ロ) Biomphalaria glabrata; (+) Biomphalaria tenagophila; $(\bullet)$ Biomphalaria straminea; (A) Lymnaea columella, $(\diamond)$ Melanoides tuberculatus 
Miracema, Natividade, Porciúncula, and Santo Antônio de Pádua), sent by Fundação Nacional de Saúde (Funasa). Those samples were included in CMIOC and, among the planorbid species, $B$. glabrata was present in all districts of Porciúncula. In the present study, this snail vector was only found in one district of Porciúncula, although no specific control actions have been performed. It is possible that the reduction of those molluscs in the area is due to the current environmental transformations occurred, as it was informed by local people.

Concerning the other natural vectors of schistosomiasis, the distributional pattern of $B$. tenagophila and $B$. straminea were extended. The first species was previously recorded in the Metropolitana Mesoregion (29 municipalities, except Mesquita), Centro Fluminense Mesoregion (16 municipalities), Baixadas Mesoregion (9 municipalities except Arraial do Cabo), Sul Fluminense Mesoregion (13 municipalities except Parati), Norte Fluminense Mesoregion (9 municipalities), including 76 municipalities (Paraense 1986, Thiengo et al. 1998, 2001, 2002a,b, 2004a,b). The present data record this species in all municipalities from Noroeste Fluminense Mesoregion, totalling 89 municipalities, thus confirming the prevalence of this species in Rio de Janeiro. As to B. straminea, the

TABLE II

List of types of cercariae and the localities where they were found in the Noroeste Fluminense Mesoregion of the state of Rio de Janeiro

\begin{tabular}{|c|c|c|c|}
\hline \multirow[b]{2}{*}{ Municipalities } & \multicolumn{2}{|l|}{ Trematode } & \multirow[b]{2}{*}{ Mollusc host } \\
\hline & Larval stages & Possible family & \\
\hline Aperibé & Echinostome cercaria & Echinostomatidae & Heleobia sp. \\
\hline Bom Jesus de Itabapoana & $\begin{array}{l}\text { Ornatae cercaria (Xiphidiocercariae) } \\
\text { Xiphidiocercariae }\end{array}$ & Haplometridae or Macroderoidae & $\begin{array}{l}\text { L. columella } \\
\text { B. tenagophila }\end{array}$ \\
\hline Cambuci & $\begin{array}{l}\text { Ubiquita cercaria (Xiphidiocercariae) } \\
\text { Echinostome cercaria } \\
\text { Ornatae cercaria (Xiphidiocercariae) } \\
\text { Cercaria de cauda simples } \\
\text { Ornatae cercaria (Xiphidiocercariae) } \\
\text { Ornatae cercaria (Xiphidiocercariae) }\end{array}$ & $\begin{array}{l}\text { Microphallidae } \\
\text { Echinostomatidae } \\
\text { Haplometridae or Macroderoidae } \\
\text { Haplometridae or Macroderoidae } \\
\text { Haplometridae or Macroderoidae }\end{array}$ & $\begin{array}{l}\text { B. tenagophila } \\
\text { B. tenagophila } \\
\text { D. lucidum } \\
\text { D. lucidum } \\
\text { D. depressissimum } \\
\text { L. columella }\end{array}$ \\
\hline Italva & $\begin{array}{l}\text { Echinostome cercaria } \\
\text { Strigid cercaria } \\
\text { Xiphidiocercariae } \\
\text { Strigid cercaria }\end{array}$ & $\begin{array}{l}\text { Echinostomatidae } \\
\text { Strigeidae or Diplostomatidae } \\
\overline{\text { Strigeidae or Diplostomatidae }}\end{array}$ & $\begin{array}{l}\text { B. tenagophila } \\
\text { B. tenagophila } \\
\text { Pomacea sp. } \\
\text { D. lucidum }\end{array}$ \\
\hline Itaocara & $\begin{array}{l}\text { Echinostome cercaria } \\
\text { Xiphidiocercariae } \\
\text { Strigid cercaria } \\
\text { Ornatae cercaria (Xiphidiocercariae) }\end{array}$ & $\begin{array}{l}\text { Echinostomatidae } \\
\text { Strigeidae or Diplostomatidae } \\
\text { Haplometridae or Macroderoidae }\end{array}$ & $\begin{array}{l}\text { B. tenagophila } \\
\text { B. tenagophila } \\
\text { B. straminea } \\
\text { D. lucidum }\end{array}$ \\
\hline Itaperuna & $\begin{array}{l}\text { Ornatae cercaria (Xiphidiocercariae) } \\
\text { Ornatae cercaria (Xiphidiocercariae) } \\
\text { Ornatae cercaria (Xiphidiocercariae) } \\
\text { Parapleurolophocercus cercaria } \\
\text { Echinostome cercaria }\end{array}$ & $\begin{array}{l}\text { Haplometridae or Macroderoidae } \\
\text { Haplometridae or Macroderoidae } \\
\text { Haplometridae or Macroderoidae } \\
\text { Echinostomatidae }\end{array}$ & $\begin{array}{l}\text { D. lucidum } \\
\text { D. cimex } \\
\text { L. columella } \\
\text { Heleobia } \mathrm{sp} . \\
\text { Heleobia } \mathrm{sp} .\end{array}$ \\
\hline Laje do Muriaé & $\begin{array}{l}\text { Echinostome cercaria } \\
\text { Ornatae cercaria (Xiphidiocercariae) }\end{array}$ & $\begin{array}{l}\text { Echinostomatidae } \\
\text { Haplometridae or Macroderoidae }\end{array}$ & $\begin{array}{l}\text { D. lucidum } \\
\text { B. tenagophila }\end{array}$ \\
\hline Miracema & $\begin{array}{l}\text { Pleurolophocercus cercaria } \\
\text { Ubiquita cercaria (Xiphidiocercariae) } \\
\text { Ornatae cercaria (Xiphidiocercariae) } \\
\text { Ubiquita cercaria (Xiphidiocercariae) }\end{array}$ & $\begin{array}{l}\text { Opistorchiidae, Cryptogonimidae } \\
\text { or Heterophyidae } \\
\text { Microphallidae } \\
\text { Haplometridae or Macroderoidae } \\
\text { Microphallidae }\end{array}$ & $\begin{array}{l}\text { M. tuberculatus } \\
\text { Pomacea } \text { sp. } \\
\text { P. marmorata } \\
\text { B. tenagophila }\end{array}$ \\
\hline Porciúncula & $\begin{array}{l}\text { Pleurolophocercus cercaria } \\
\text { Strigid cercaria }\end{array}$ & $\begin{array}{l}\text { Opistorchiidae, Cryptogonimidae } \\
\text { or Heterophyidae } \\
\text { Strigeidae or Diplostomatidae }\end{array}$ & $\begin{array}{l}\text { Heleobia } \mathrm{sp} . \\
\text { B. glabrata }\end{array}$ \\
\hline Santo Antônio de Pádua & $\begin{array}{l}\text { Strigid cercaria } \\
\text { Echinostome cercaria } \\
\text { Ubiquita cercaria (Xiphidiocercariae) } \\
\text { Xiphidiocercariae } \\
\text { Ubiquita cercaria (Xiphidiocercariae) } \\
\text { Ornatae cercaria (Xiphidiocercariae) }\end{array}$ & $\begin{array}{l}\text { Strigeidae or Diplostomatidae } \\
\text { Echinostomatidae } \\
\text { Microphallidae } \\
\text { Microphallidae } \\
\text { Haplometridae or Macroderoidae }\end{array}$ & $\begin{array}{l}\text { B. tenagophila } \\
\text { B. tenagophila } \\
\text { B. tenagophila } \\
\text { Pomacea sp. } \\
\text { Pomacea sp. } \\
\text { L. columella }\end{array}$ \\
\hline São José de Ubá & Ornatae cercaria (Xiphidiocercariae) & Haplometridae or Macroderoidae & A. nordestensis \\
\hline
\end{tabular}


geographical distribution previously known in 22 municipalities in the state (Thiengo et al. 2004a), is now extended to include Aperibé, Cambuci, Itaocara, and Santo Antônio de Pádua.

In relation to the non-vector planorbid species, $D$. anatinum was the most common, followed by $D$. lucidum. In the previous studies the most frequent species was: $D$. anatinum in the Metropolitana, Norte, and Centro Fluminense Mesoregions (Thiengo et al. 2001, 2002a, 2004b); D. cimex in Baixadas Mesoregion (Thiengo et al. 2002b) and D. lucidum in the Sul Fluminense Mesoregion (Thiengo et al. 2004a). The distribution of A. nordestensis, previously known in 32 municipalities in the state (Thiengo et al. 1998, Santos et al. 1999, Thiengo et al. 2001, 2002a,b, 2004a,b) is now extended to include Aperibé, Cambuci, Bom Jesus de Itabapoana, Italva, Itaperuna, Miracema, Natividade, Santo Antônio de Pádua, São José de Ubá, Porciúncula, and Varre-Sai. Recently Fernandez et al. (2006) reported $P$. guadeloupensis for the first time in the state of Rio de Janeiro and provided the geographical distribution of the genus Plesiophysa in Brazil, as well as some physical and chemical characteristics of the habitats.

Of the remaining Pulmonata species, P. marmorata was the most frequent. The same was observed in the previously studied Mesoregions, e.g., Baixadas, Centro, Sul, and Norte Fluminense Mesoregions (Thiengo et al. 2002a,b, 2004a,b). In the Metropolitana Mesoregion, including the Serrana Microregion, the predominant species was P. cubensis (Thiengo et al. 1998, 2001). The natural vector of fascioliasis, L. columella, was found in all municipalities of the Noroeste Fluminense Mesoregion, showing wide range in the state.

The Afro-Asian thiarid M. tuberculatus was found in 11 out of the 13 municipalities, generally in dense populations. According to Pointier and Delay (1995), the biological and parthenogenetic reproductive characteristics of M. tuberculatus make this species a good invader. Recently, Giovanelli et al. (2005) evaluated the habitat preference of freshwater snails in relation to environmental factors and the presence of the snail $M$. tuberculatus and pointed out no evidence of competition among those species found in the same habitat.

As to the Prosobranchia species, morphological and molecular studies are being undertaken on samples of Pomacea from six Mesoregions of Rio de Janeiro, in order to identify them and preliminary results are published elsewhere (Cowie et al. 2006). The snails collected from 10 municipalities are quite different from those reported by Thiengo et al. (2004b) in the Norte Fluminense Mesoregion.

Concerning the Ancylidae, G. ticaga was the commonest species, occurring in almost all surveyed municipalities, as it was observed in the previously studied Mesoregions. Specimens of Gundlachia sp. found in four municipalities (Cambuci, Itaperuna, Miracema, and Santo Antônio de Pádua) are sharply different from G. ticaga concerning the shell morphology and sculpture. This species was also found in Sul and Centro Fluminense Mesoregions (Thiengo et al. 2002a, 2004a). Additional morphological studies are being done with Gundlachia sp. and Ferrissia sp., thus proving that the latter is quite different from Ferrissia gentiles Lanzer, 1991 found in South Brazil.

Similarly to the other above-mentioned Mesoregions, the xiphidiocercariae group (including Ornatae cercariae and Ubiquita cercariae) was the most frequent found in the molluscs. As to schistosomiasis, although the number of positive cases must be seen as underestimated information (37 cases in the present study) because of the limitation of logistic resources available to Funasa, the results of the coproscopical surveys carried out from 2000 to 2005 showed 338 positive schistosomiasis cases in the state, specifically in Barra Mansa, Carmo, Duas Barras, Paracambi, Porciúncula, São Gonçalo, and Sumidouro municipalities.

Further studies involving space and geographic distribution data of the freshwater gastropods in Rio de Janeiro correlated to snails habitat preferences will be undertaken aiming to improve knowledge on the biodiversity, to discriminate areas of epidemiological importance for schistosomiais as well as data for supplying public health risk maps.

\section{ACKNOWLEDGEMENTS}

To Biologist Márcio da Silva Loureiro for technical assistance.

\section{REFERENCES}

CIDE-Centro de Informações e Dados do Rio de Janeiro 2001. Secretaria do Estado de Planejamento, Desenvolvimento Econômico e Turismo, Rio de Janeiro: map.

Cowie R, Hayes K, Thiengo SC 2006. What are apple snails? Confused taxonomy and some preliminary resolution. In $\mathrm{R}$ Joshi, Global Advances in Ecology and Management of Golden Apple Snails (in print).

Fernandez MA, Thiengo SC, Paraense WL 2006. Primeiro registro de Plesioplysa guadeloupensis ("Fischer" Mazé, 1883) no Estado do Rio de Janeiro. Rev Bras Zool (in print).

Giovanelli A, Silva CLPAC, Leal GBE, Baptista DF 2005. Habitat preference of freshwater snails in relation to environmental factors and the presence of the competitor snail Melanoides tuberculata (Müller, 1774). Mem Inst Oswaldo Cruz 100: 169-176.

IBGE 1995. Síntese da documentação histórico-administrativa e geográfica dos Estados do Brasil - Rio de Janeiro. Fundação Instituto Brasileiro de Geografia e Estatística, Rio de Janeiro.

Paraense WL 1986. Distribuição dos caramujos no Brasil. In FA Reis, I Faria, N Katz (eds), Modernos Conhecimentos sobre Esquistossomose Mansônica, Biblioteca da Academia Mineira de Medicina, Belo Horizonte, p. 117-128.

Pointier JP, Delay B 1995. Spread of the introduced freshwater snail Melanoides tuberculata (Müller, 1774) on the island of Guadeloupe, French West Indies (Prosobranchia, Thiaridae). Haliotis 24: 109-116.

Santos SB, Monteiro DP, Fernandez, MA, Thiengo SC 1999. Primeiro registro de Antillorbis nordestensis (Lucena) (Molusca, Gastropoda, Planorbidae) para a Ilha Grande, Angra dos Reis, Rio de Janeiro. Rev Bras Zool 16: 257-259.

Schell S 1970. How to Know the Trematodes, WMC Brown Co. Publ, Dubuque, 355 pp. 
Thiengo SB, Fernandez MA, Boaventura MF, Stortti MA 1998. A survey of gastropods in the Microrregião Serrana of Rio de Janeiro, Brazil. Mem Inst Oswaldo Cruz 93(Suppl. I): 233-234.

Thiengo SB, Fernandez MA, Boaventura MF, Grault CE, Silva HFR, Mattos AC, Santos SB 2001. Freshwater snails and schistosomiasis mansoni in the state of Rio de Janeiro, Brazil: I- Metropolitan Mesoregion. Mem Inst Oswaldo Cruz 96(Suppl.): 177-184.

Thiengo SB, Fernandez MA, Boaventura MF, Santos SB, Mattos AC 2002a. Freshwater snails and schistosomiasis mansoni in the state of Rio de Janeiro, Brazil: II- Centro Fluminense Mesoregion. Mem Inst Oswaldo Cruz 97: 621-626.
Thiengo SB, Fernandez MA, Boaventura MF, Magalhães MG, Santos SB 2002b. Freshwater snails and schistosomiasis mansoni in the state of Rio de Janeiro, Brazil: III- Baixadas Mesoregion. Mem Inst Oswaldo Cruz 97(Suppl. I): 43-46.

Thiengo SB, Mattos AC, Boaventura MF, Fernandez MA 2004a. Freshwater snails and schistosomiasis mansoni in the state of Rio de Janeiro, Brazil: IV- Sul Fluminense Mesoregion. Mem Inst Oswaldo Cruz 99: 275-280.

Thiengo SB, Mattos AC, Boaventura MF, Loureiro MS, Santos SB, Fernandez MA 2004b. Freshwater snails and schistosomiasis mansoni in the state of Rio de Janeiro, Brazil: VNorte Fluminense Mesoregion. Mem Inst Oswaldo Cruz 99(Suppl. I): 99-103. 
